\title{
Optimalisasi Inisiasi Destinasi Wisata Datar Peundey Sebagai Pendorong Ekonomi Masyarakat
}

\section{Optimalization of The Initiation of The Datar Peundeuy Tourism Destination As A Community Economic Booster}

\author{
Khiyarullah ${ }^{1}$ \\ 1Program Studi Ekonomi Syariah Fakultas Ekonomi Islam Universitas Djuanda Bogor, Jl Tol Ciawi No. 1 \\ Kotak Pos 35 Bogor 16720, e-mail: andikhiyar@gmail.com
}

(Diterima: 25-06-2020; Ditelaah: 15-12-2020; Disetujui: 10-06-2021)

\begin{abstract}
Abstrak
Inisiasi destinasi wisata Datar Peundeuy dilakukan karena melihat potensi kekayaan alam dan keindahan panorama yang dimilikinya, akses jalan yang mudah, pelataran rerumputan sangat berpotensi dijadikan sebagai lokasi camping, kerapihan pohon juga berpotensi untuk dipasangkan ayunan untuk bersantai, dan dapat dijangkau oleh semua kalangan. Pelaksanaan kegiatan ini menggunakan metode Pendekatan Orang Dewasa (POD) yang dilakukan secara partisipatif dengan metode tanya jawab dan diskusi peningkatan pengetahuan tentang dan penggalian potensi wisata di Desa Padamulya. Hasil kegiatan Inisiasi Destinasi Wisata Halal Datar Peundeuy ini, yaitu : Terbentuknya POKDARWIS, Destinasi Wisata Halal Datar Peundeuy telah berproses, Publikasi Destinasi Wisata, Pemahaman Masyarakat terkait Destinasi Wisata Halal yang berlokasi di desa Padamulya Kecamatan Pasirkuda Kabupaten Cianjur.
\end{abstract}

Kata Kunci: Destinasi Wisata, Ekonomi Masyarakat, Inisiasi

\begin{abstract}
The initiation of the Datar Peundeuy tourist destination was carried out because it saw the potential for natural wealth and the beauty of the panorama it had, easy road access, the grassy courtyard has the potential to be used as a camping location, the neatness of trees also has the potential to be paired with swings to relax, and can be reached by all people. The implementation of this activity uses the Adult Approach (POD) method which is carried out in a participatory manner with a question and answer method and discussions to increase knowledge about and explore tourism potential in Padamulya Village. The results of the Initiation of Halal Tourism Destinations Datar Peundeuy, namely: The formation of POKDARWIS, Halal Tourism Destinations Datar Peundeuy has been processed, Publication of Tourist Destinations, Public Understanding of Halal Tourism Destinations located in Padamulya Village, Pasirkuda District, Cianjur Regency.
\end{abstract}

Keywords: Community Economy, Initiation, Tourism Destinations

\section{PENDAHULUAN}

Desa Padamulya mempunyai daya tarik wisata tersendiri dari segi cocok tanam, pemandangan alam dan suasana desa yang masih asri. Daya tarik atau atraksi wisata adalah suatu bentukan dan/atau aktivitas dan fasilitas yang berhubungan serta dapat menarik minat wisatawan atau pengunjung untuk datang ke suatu daerah/tempat tertentu (Kamilet al, 2017). Atraksi adalah jantung dari kegiatan pariwisata dan merupakan alasan utama mengapa wisatawan mengunjungi suatu area, termasuk desa sebagai tujuan wisata (Hakim, 2014). Dibalik pedesaannya yang terpencil terdapat tempat-tempat indah dan menarik untuk dijadikan tempat wisata diantaranya Kebun Teh dan Curug Citambur, termasuk juga hutan pinus yang terkenal dengan sebutan Datar Peundeuy. 
Pariwisata telah memberikan devisa yang cukup besar bagi Negara Indonesia, khususnya dalam era globalisasi (Hamid et al, 2016). Pemilihan program inisiasi destinasi wisata Datar Peundeuy dilakukan agar hal tersebut dapat terwujud, selain itu karena melihat potensi kekayaan alam dan keindahan panorama yang dimilikinya, akses jalan yang melintasi Datar Peundeuy adalah salah satu jalan yang paling bagus di Desa, pelataran rerumputan sangat berpotensi dijadikan sebagai lokasi camping, kerapihan pohon juga berpotensi untuk dipasangkan ayunan untuk bersantai, dan masih banyak lagi potensi yang dimiliki Datar Peundeuy menjadi sasaran wisatawan dan dapat dijangkau oleh semua kalangan.

Adapun upaya awal pada program inisiasi destinasi wisata ini dapat dilakukan melalui pengembangan master plan dan diferensiasi destinasi wisata yang dapat membantu masyarakat Desa dalam memunculkan ide-ide disetiap penyusunan strategi untuk pengembangan potensi wisata. Program ini juga dapat dipublikasikan melalui semua media, baik itu media cetak ataupun media sosial seperti instagram, facebook, whatsapp dengan postingan yang menarik. Keberhasilan pengelola desa wisata dalam mempengaruhi persepsi pengunjung dengan alat-alat promosinya dapat mencetuskan keputusan berkunjung. (Atun Yulianto al, 2018) Hal inilah yang menjadi kebanggaan tersendiri dari masyarakat Desa Padamulya, terutama masyarakat yang tinggal di sekitar Datar Peundeuy, karena dengan adanya program ini juga sesuai dengan harapan masyarakat bahwa inisiasi destinasi wisata dapat menjadi pendorong perekonomian masyarakat Desa.

\section{METODE PELAKSANAAN}

Pelaksanaan kegiatan dimulai dengan persiapan mencari informasi yang akan dibahas lalu survey awal untuk melihat kondisi kesiapan di lapangan, setelah itu adakanlah kegiatan sosialisasi pertama, kemudian dilanjutkan lagi dengan observasi, setelah itu diadakan sosialisasi kedua dan sampai pada Rapat Inisiasi Pembentukan Destinasi Wisata Halal. Dalam kegiatan ini semua elemen Desa terlibat termasuk Kepala Desa Padamulya. Pelaksanaan kegiatan ini menggunakan metode Pendekatan Orang Dewasa (POD) yang dilakukan secara partisipatif dengan metode tanya jawab dan diskusi peningkatan pengetahuan tentang dan penggalian potensi wisata di Desa Padamulya.

\section{HASIL \& PEMBAHASAN}

Kegiatan Inisiai Destinasi Wisata Halal ini dihadiri oleh Kepala Desa dan seluruh elemen Desa Padamulya. Kegiatan ini dilakukan mulai dari survey sampai pada rapat Inisisasi Destinasi Wisata Halal di Datar Peundeuy. Tahapan kegiatan dilakukan dalam meningkatkan Ekonomi Masyarakat.

Adapun hasil dari kegiatan Inisisasi Destinasi Wisata Halal di Datar Peundeuy adalah sebagai berikut: 
1. Aparatur Desa setelah dilakukan sosialisasi pemahaman tentang destinasi wisata halal telah memahami apa yang disampaikan meskipun memang belum pada tahap memahami yang secara detail.

2. Pada saat sosialisasi pemahaman masyarakat meningkat yang belum mengetahui menjadi tahu.

3. Setelah pemaparan dilakukan diskusi agar masyarakat dapat memahami materi yang dibahas dengan mengajukan pertanyaan dan sharing mengenai yang dibahas dan masyarakat antusias menyampaikan berbagai pertanyaan.

4. Pemahaman terhadap masyarakat mengenai apa perbedaan antara destinasi wisata halal dan destinasi wisata konvensional serta memberi pemahaman bagaimana majunya peradaban Islam terdahulu karena pengelolaan destinasi wisata halal. Sehigga dengan pemahaman tersebut masyarakat akan menimbulkan rasa peduli serta ingin berkontribusi langsung pada program ini.

5. Selain hasil nonfisik pada kegiatan sosialisasi ini, ada juga hasil fisik dalam program Inisisasi Destinasi Wisata Halal di Datar Peundeuy yaitu berbentuk foto rekomendasi spot wisata dan publikasi ke beberapa Media Online dan Media social yang meliputi Media Daerah Cianjur Provinsi Jawa Barat dan nasional.

Dalam Pelaksanakan program Inisiasi Destinasi Wisata Halal ini dengan melakukan beberapa tahap diantaranya: Sosialisasi, Observasi, Rapat dan Diskusi dengan Kepala Desa, Kepala Dusun Cibimbin, dan para tokoh masyarakat maupun tokoh pemuda lainnya. Adapun penjelasan dari tpelaksanan tersebut ialah :

a. Sosialisasi 1

Program Inisiasi Destinasi Wisata Halal ini dimulai dari sosialisasi pertama bersama Kepala Dusun Cibimbin dan beberapa perwakilan dari masyarakat di lokasi destinasi wisata halal Datar Peundeuy Desa Padamulya. Adapun rincian kegiatan, adapun rincian kegiatan sosialisasi pertama sebgai berikut:

1. Pembukaan dari salah satu mahasiswa

2. Perkenalan dari Mahasiswa mengenai identitas dan beberapa program yang akan dilaksanakan di Desa Padamulya termasuk program Inisiasi Destinasi Wisata Halal.

3. Penyampaian informasi dari Kepala Dusun Cibimbin mengenai sejarah singkat, permasalahan, dan rencana kedepan untuk Datar Peundeuy sebagai Destinasi Wisata Halal.

4. Pemaparan informasi dari mahasiswa terkait destinasi wisata yang ada di daerah lain dan mempunyai kesamaan dengan Hutan Pinus Datar Peundeuy.

5. Kemudian diskusi terbuka antara mahasiswa dan Kepala Dusun Cibimbin bersama masyarakat sekitar.

6. Setelah itu acara ditutup dengan makan nasi liwet bersama.

b. Observasi

Observasi langsung ke lokasi sebagai lanjutan dari sosialisasi pertama bersama Kadus Cibimbin dan masyarakat sekitar Datar Peundeuy. Kegiatan observasi ini dihadiri oleh Sekretaris Desa Padamulya dan Aparatur Desa lainnya. Diawali dengan diskusi seputar datar Peundeuy, kemudian mahasiswa menyebar dan beberapa mahaisiwa 
mendokumentasikan gambar. Observasi ini bertujuan untuk menggali potensi wisata, kekayaan alam dan keindahan panorama yang dimiliki Desa Padamulya.

c. Sosialisasi 2

Setelah observasi langsung ke lokasi kami melanjutkan program Inisiasi Destinasi Wisata Halal dengan agenda sosialisasi kedua di Balai Desa, pada sosialisasi kedua ini berlangsung dengan diskusi sederhana bersama Aparatur Desa, Tokoh Pemuda, dan beberapa dari Organisasi Masyarakat. Diskusi ini bertujuan untuk menyampaikan hasil observasi dan merencanakan rapat Inisiasi Destinasi Wisata Halal bersama Kepala Desa dan Elemen Masyarakat.

d. Rapat Inisiasi Destinasi Wisata Halal

Mahasiswa bersama dengan aparatur desa setempat mengadakan Rapat Inisiasi Destinasi Wisata Halal, dimana aparatur desa beserta tokoh-tokoh pemuda menjelaskan apa saja yang diinginkan untuk Datar Peundeuy nantinya, sejauh mana pergerakan yang telah dilakukan, apa saja rencana yang ingin mereka kerjakan.

Adapun rincian dan penjelasan dari kegiatan rapat inisiasi destinasi wisata halal sebagai berikut:

1. Mahasiswa menjelaskan mengenai wisata halal, tujuan, manfaat, serta hasil yang akan dicapai nantinya.

2. Mahasiswa memberikan saran dan masukan ide mengenai apa saja yang dapat direalisasikan untuk Datar Peundeuy dengan dana seminim mungkin dengan memanfaatkan sumber daya alam di Desa Padamulya sendiri. Kemudian, saran untuk bagaimana agar Datar Peundeuy ini dapat diketahui oleh orang banyak, nantinya aparatur desa dapat berkoordinasi dengan mahasiswa kembali bila memerlukan bantuan namun dapat juga berkoordinasi langsung dengan media-media massa yang ada sebagai upaya branding Datar Peundeuy kepada masyarakat luas. Selain itu mahasiswa memberikan beberapa gambar yang dapat dibuat nantinya untuk diaplikasikan di Datar Peundeuy.

3. Saran serta masukan dari Kepala Desa untuk semua yang hadir, baik mahasiswa, aparatur desa setempat, tokoh-tokoh yang hadir, khususnya Kelompok Sadar Wisata yang ada di Desa Padamulya.

4. Penutupan sekaligus foto bersama Kepala Desa dan aparatur desa setempat di Datar Peundeuy.

Indikator keberhasilan kegiatan ini adalah keseriusan dari Masyarakat dan Desa Padamulya mengikuti partisipasi dalam kegiatan Inisiasi Destinasi Wisata Halal dan juga perhatian kusus dari Dinas Pariwisata Kabupaten Cianjur. Rencana tindak lanjut pada program inisiasi destinasi wista halal ialah dengan memonitoring perkembangan Datar Peundeuy sebagai destinasi wisata halal baru di Desa Padamulya, baik itu target kerjanya maupun aturan yang mencakup tentang ruang lingkup wisata halal dan sesuai dengan hukum islam. Juga senantiasa menjadi fasilitator antara desa dan media untuk menyebar luaskan berita terkait Destinasi Wisata Halal di Datar Peundeuy guna untuk mendapatkan perhatian khusus dari Kabupaten Cianjur dan Provinsi Jawa Barat, baik itu 
perhatian dalam bentuk bantuan anggaran atau pun perbaikan akses jalan menuju ke lokasi Destinasi Wisata Halal Datar Peundeuy di Desa Padamulya.

Hasil fisik dan non fisik program Inisiasi Destinasi Wisata Halal Datar Peundeuy ini, yaitu : Terbentuknya (POKDARWIS), Destinasi Wisata Halal Datar Peundeuy telah berproses, Publikasi Destinasi Wisata, Pemahaman Masyarakat terkait Destinasi Wisata Halal yang berlokasi di desa Padamulya Kecamatan Pasirkuda Kabupaten Cianjur.

Tabel 1. Capaian program

\begin{tabular}{|l|c|c|}
\hline \multicolumn{1}{|c|}{ Capaian } & Sebelum & Sesudah \\
\hline Terbentuknya (POKDARWIS) & $50 \%$ & $80 \%$ \\
\hline $\begin{array}{l}\text { Destinasi Wisata Halal Datar Peundeuy telah } \\
\text { berproses }\end{array}$ & $40 \%$ & $70 \%$ \\
\hline $\begin{array}{l}\text { Pemahaman Masyarakat terkait Destinasi } \\
\text { Wisata Halal }\end{array}$ & $40 \%$ & $70 \%$ \\
\hline Publikasi Destinasi Wisata & $30 \%$ & $70 \%$ \\
\hline $\begin{array}{l}\text { kesadaran masyarakat terhadap pentingnya } \\
\text { inisiasi Destinasi wisata halal terhadap } \\
\text { perekonomian masyarakat }\end{array}$ & $50 \%$ & $80 \%$ \\
\hline
\end{tabular}

Masalah yang dihadapi dari kegiatan ini adalah kurangnya fasilitas pendukung dalam berjalannya kegiatan sosialisasi seperti dari segi sarana prasarana, kemudian masih banyaknya masyarakat yang mempunyai kegiatan yang lain seperti bertani, sehingga belum dapat mengikuti kegiatan Inisiasi Destinasi Wisata Halal Datar Peundeuy. Terdapat permasalahan atau kendala yang dihadapi dalam optimalisasi insiasi pembentukan destinasi wisata Datar Peundeuy sebagai pendorong ekonomi masyarakat desa padamulya:

a. Kurangnya kesadaran masyarakat tentang pentingnya destinasi wisata dalam meningkatkan perekonomian masyarakat di Desa Padamulya.

b. Kurangnya pengetahuan masyarakat tentang bagaimana cara membangun dan mengembangkan potensi sumber daya alam yang dimiliki dikawasan Desa Padamulya

c. Kurangnya kesadaran masyarakat menggali potensi wisata halal di Desa Padamulya.

d. Kurangnya kesadaran masyarakat untuk melestarikan kekayaan alam Desa Padamulya.

e. Masih terhambat anggaran.

\section{KESIMPULAN}

Pelaksanaan kegiatan sosialisasi ini menunjukan bahwa adanya peningkatan kesadaran serta tekad dari Kepala Desa untuk secepatnya Destinasi Wisata Halal Datar Peundeuy berkembang sehingga dapat meningkatkan perekonomian bagi masyarakat di Desa Padamulya. Kemudian para masyarakat yang ikutserta dalam kegiatan Inisiasi Destinasi Wisata Halal Datar Peundeuy berlangsung memberikan respon yang sangat baik dari segi 
perizinan tempat, pemaparan, sharing, dan pada saat diskusi. Masyarakat sangat antusias dalam mengikuti kegiatan Inisiasi Destinasi Wisata Halal Datar Peundeuy ini terlihat dari minat masyarakat untuk menerapkan sistem yang ada dalam ekonomi syariah setelah mengetahui banyak manfaat yang ada dalam ekonomi syariah.

\section{DAFTAR PUSTAKA}

Andriani, Dini dkk. 2015. Kajian Pengembangan Wisata Syariah. Diakses pada tanggal 21 Maret 2017 melalui http://www.kemenpar.go.id /userfiles/2015\%20Kajian\%20 Pengembangan\%20Wisata\%20 syariah.pdf.

Atun Yulianto, Jurnal Media Wisata, Volume 16, Nomor 2, November 2018.

Customer User Manual-Restoran, diakses pada 21 Juli 2017 dari http://www.halalmui.org/ images/stories/pdf/Manu al-CEROLRestaurant(Indo1.2).pdf.

Hakim, Luchman. 2014. Etnobotani dan Manajemen Kebun-Pekarangan Rumah: Ketahanan Pangan, Kesehatan, dan Agrowisata. Malang: Penerbit Selaras.

Hananto, Erwin. 2016.Pengertian dan Tujuan Sertifikasi Halal. Diakses pada tanggal 10 April 2017. Melalui http://www.konsultanhalal.n et/2016/05/pengertiandantujuan-sertifikasi-halal.html. 